\title{
TFG/NR4A3 Fusion Gene
}

National Cancer Institute

\section{Source}

National Cancer Institute. TFG/NR4A3 Fusion Gene. NCI Thesaurus. Code C99573.

A fusion gene that results from a rearrang ement of chromosomes 3 and 9 which fuses exon 6 of the TFG gene and the entire coding sequence of the NR4A3 gene. This rearrangement is associated with extraskeletal myxoid chondrosarcoma. 